\title{
IMPLIKASI GERAKAN PEMBAHARUAN K.H. MAS ABDURAHMAN (1875- 1943) DI BANTEN
}

\author{
Agus Kusman \\ IAIN Syekh Nurjati Cirebon (agustonjong2016@gmail.com)
}

\begin{abstract}
The beginning of the 20th century is the starting point of Islamic transformation in Indonesia. Various changes and renewal of social, economic, cultural, political to religious that appear massively like mushrooms in the rainy season. This is what is often called the culmination of modernization of Islam. In a vibrant atmosphere that is K.H. Mas Abdurrahman was present on the Indonesian history stage by contributing his energy, thought and spirit. K.H. Mas Abdurahman is a famous scholar in Banten. He initiated the establishment of the Mathla'ul Anwar madrasah, which then made the educational institution grow rapidly.
\end{abstract}

Keywords: K.H. Mas Abdurahman, renewal, Banten.

\begin{abstract}
Abstrak
Awal abad ke 20 merupakan titik tolak transformasi Islam di Indonesia. Berbagai perubahan dan pembaharuan baik sosial, ekonomi, budaya, politik hingga agama yang muncul secara masif seperti jamur di musim hujan. Inilah yang sering kali disebut sebagai puncak modernisasi Islam. Dalam suasana yang bergelora itulah K.H. Mas Abdurrahman turut hadir di panggung sejarah Indonesia dengan menyumbangkan tenaga, pemikiran serta jiwanya. K.H. Mas Abdurahman adalah ulama yang terkenal di Banten. Beliau memprakarsai berdirinya madrasah Mathla'ul Anwar, yang kemudian membuat institusi pendidikan itu berkembang pesat.
\end{abstract}

Kata Kunci: K.H. Mas Abdurahman, pembaharuan, Banten.

\section{A. Pendahuluan}

Awal abad ke 20 merupakan titik tolak transformasi Islam di Indonesia. Berbagai perubahan dan pembaharuan baik sosial, ekonomi, budaya, politik hingga agama yang muncul secara masif seperti jamur di musim hujan. Inilah yang sering kali disebut puncak modernisasi Islam. Namun demikian, proses ini bukanlah datang begitu saja tetapi setelah melalui berbagai proses yang pastinya juga dipengaruhi oleh berbagai faktor, di antaranya intensifnya hubungan Nusantara dengan Timur Tengah melalui peranan haji ${ }^{1}$ dan juga

1 Perkembangan Islam tidak lepas dari meningkatnya jumlah kaum Muslim yang berhaji baik hanya sebatas menjalankan rukun lima ini saja pelajar yang melakukan studi lanjutan ${ }^{2}$, serta munculnya teknologi percetakan yang memungkinkan tersebarnya ide-ide baru dengan lebih cepat. Dalam kurun waktu tersebut, transmisi pengetahuan

atau ada yang memutuskan menetap sementara sebelum kemudian kembali ke tanah air, meskipun kelompok kedua ini jumlahnya relatif sedikit. Tidak heran, jika berbagai pemikiran baru berkembang seiring dengan peningkatan jumlah mereka yang berhaji. Azyumardi Azra, Jaringan Ulama Timur Tengah dan Kepulauan Nusantara Abad XVII dan XVIII: Melacak Akar-Akar Pembaharuan Pemikiran Islam di Indonesia, (Bandung : Penerbit Mizan, 1998), hlm. 20

${ }^{2}$ Studi lanjutan adalah kegiatan belajar para pelajar dan ulama muslim Nusantara yang memperdalam pengetahuan agama dan bahkan tidak sedikit yang menjadi pengajar di salah satu Universitas di Mesir, Mekah, ataupun Madinah. kedatangan ide-ide baru oleh pelajar yang baru lulus membawa angin segar bagi kaum muslim lokal untuk terus meningkatkan wawasan agama Islam. Didin Nurul Rosyidin, Wajah Baru Islam Indonesia (Kontestasi Gerakan Keislaman Awal Abad 20), (Cirebon:Nurjati Press, 2012), hlm. 13. 
Islam dan juga transformasi masyarakat Islam di Indonesia khususnya, dan Asia Tenggara pada umumnya hingga abad ke 19 dan 20 tidak lepas dari peran para pelajar yang pulang dari Hijaz. Melalui mereka, pemahaman ajaran Islam beserta teks-teks dan lembaga pendidikan Islam dalam bentuknya muncul dan berkembang di Nusantara.

Para haji yang baru pulang secara mandiri maupun kelompok berinisiatif mendirikan berbagai organisasi persyarikatan Islam modern. Sebagian besar gerakan ini diilhami oleh gagasangagasan Islam modernis dan munculnya tantangan-tantangan baru di tempat asal. Sebagian lagi dilatarbelakangi oleh perbedaan corak, asal-usul, dan kecenderungan keagamaan mereka. Seperti pada tahun 1905, masyarakat Arab yang tinggal di Jakarta yang melihat bidang pendidikan sebagai lahan paling menjanjikan dalam melakukan reformasi kaum Muslim mendirikan sebuah organisasi bernama Jami'atul Khair. Sebagai langkah pertama, organisasi ini membuka Sekolah Dasar, di antara mata pelajarannya adalah aritmatika, geografi, sejarah Islam bahkan bahasa Inggris dan bahasa Melayu digunakan sebagai bahasa pengantar. Sekolah ini menerima siswa yang berasal baik anak-anak keturunan Arab maupun non-Arab. ${ }^{3}$

Selain itu tahun 1911, K.H. Abdul Halim mendirikan organisasi dengan nama Hayatul Qulub di Majalengka, Jawa Barat. Pendirian organisasi ini tidak lepas dari kesan mendalam Abdul Halim terhadap berbagai perubahan sistem pendidikan Islam di Makkah, tempat dia belajar selama tiga tahun (1908-1911). Sebagai rintisan awal, ia memfokuskan terlebih dahulu pada kegiatan pendidikan agama untuk orang dewasa yang berasal dari desa-desa sekitar. Karena memfokuskan pada pendidikan agama melalui Majelis Taklim, Abdul Halim belum bisa mendirikan lembaga pendidikan modern sebagaimana yang ia cita-citakan pada tahun-tahun awal gerakannya.

Dalam suasana yang bergelora itulah K.H Mas Abdurrahman turut hadir di panggung sejarah Indonesia dengan menyumbangkan tenaga, pemikiran serta jiwanya. Ia dilahirkan di Kampung Janaka Desa Ciput, Kecamatan Labuhan Kabupaten Pandeglang (sekarang Masuk Propinsi Banten) pada tahun $1875^{4}$. Pada tahun 1916 K.H. Mas Abdurahman

\footnotetext{
${ }^{3}$ Sartono Kartodirjo, Pengantar Sejarah Indonesia Baru: 1.500-1900 Dari Emperium Sampai Imperium Jilid I,(Jakarta: Gramedia, 1987), hlm. 377

${ }^{4}$ Anonim, Menapak Jejak Mengenal Watak, Sekilas Biografi 20 Tokoh Nahdlatul Ulama, (Jakarta: Yayasan Saifuddin Zuhri, 1994), hlm. 73-87
} 
memprakarsai berdirinya sebuah lembaga pendidikan Islam yang nantinya berkembang menjadi organisasi sosial keagamaan, yang diberi nama Mathla'ul Anwar dengan dukungan Kiai Haji Sholeh Kenanga, Kiai Haji Entol Muhamad Yasin dan lain-lain. ${ }^{5}$

Di bawah kepemimpinan K.H. Mas Abdurahman, Mathla'ul Anwar dengan cepat berkembang menjadi lembaga pendidikan dan kemudian berubah menjadi organisasi, baik di Karesidenan Banten sendiri maupun di daerah sekitarnya, terutama Karesidenan Lampung. Madrasah-madrasah yang berdiri dan bergabung ke dalam Mathla'ul Anwar diberi nama seragam yakni Madrasah Mathla'ul Anwar, sebagai pusatnya adalah Madrasah Mathla'ul Anwar Menes Banten, sedangkan cabang-cabangnya berada di kedua Karesidenan tersebut dengan jumlah puluhan bahkan ratusan lembaga.

\section{B. Perjalanan Hidup K.H. Mas}

\section{Abdurahman}

Mas Abdurahman, nama yang diberikan oleh kedua orang tuanya. Ia dilahirkan di Kampung Janaka ${ }^{6}$ Desa

\footnotetext{
5 M. Nahid Abdurrahman, Abdurrahman: Pendiri Mathla'ul Anwar tahun 1916, (Rangkasbitung: Penerbit Tawekal, t.th), hlm 15

6 Janaka adalah sebuah dusun di lereng gunung Haseupan, termasuk ke daerah Labuhan. Apabila
}

Ciput Kecamatan Labuhan, Kabupaten Pandeglang, Provinsi Banten pada tahun 1875. Gelar Mas merupakan gelar kehormatan yang diberikan secara turun menurun dan berasal dari nama seorang Senopati Pajajaran bernama Mas Jong dan Agus Ju. Mereka adalah tangan kanan raja Pajajaran bernama Pucuk Umun. $^{7}$

Setelah mukim selama sepuluh tahun di Mekkah, Mas Abdurrahman kembali ke Menes pada tahun 1910. Kepulangannya ini tidak lepas dari permintaan khusus dari salah seorang ulama Banten yang mempunyai kharismatik tinggi dan dikenal sebagai faqih (ahli hukum Islam) yakni Kiai Haji Muhamad Tubagus Sholeh yang nantinya menikahkan Mas Abdurrahman dengan salah seorang putrinya bernama Nyai Enong. Akan tetapi pernikahan ini tak berlangsung lama karena istrinya meninggal dunia pada saat menjalankan ibadah haji di Mekkah. Setelah itu, Mas Abdurrahman menikah tiga kali secara berurutan antara lain dengan Ibu Menot

kita ingin mengetahui tempat tersebut maka dari kota Menes kita menuju arah utara jika ditempuh dengan kendaraan $7 \mathrm{Km}$ karena letaknya sukar ditempuh dengan kendaraan maka harus ditempuh dengan berjalan kaki juga $7 \mathrm{Km}$ karena tempatnya adalah di atas gunung lihat M. Nahid Abdurrahman, Abdurrahman: Pendiri Mathla'ul Anwar tahun 1916 (Rangkasbitung: Penerbit Tawekal, t.th.), hlm. 2

7 Didin Nurul Rosyidin. Wajah Baru Islam Indonesia ( Kontestasi Gerakan Keislaman Awal Abad 20 ). Hlm. 33 
Aminah binti Haji Ali dari Soreang Menes, Ibu Ijot Khodijah binti Kiai Samin berasal dari Soreang Menes, dan Ibu Enjoh binti Haji Safik berasal dari Langensari, Pandeglang.

Dari ketiga pernikahan ini, ia memiliki lima belas anak yakni Emed, Muhammad Habri atau Abeh, Hamid, Enong, Eno, Adung Abdurrahman, Mariah, Bayi, Khalid, Muslim, Muslimah, Muhammad Nahid, Zahriah, Zahra, dan Munjiah. ${ }^{8}$ Ketika K.H. Mas Abdurahman memiliki anak, ia pun mengajari anak-anaknya dasar-dasar ilmu agama Islam dan setelah itu menitipkan mereka di pesantren lain dengan tujuan mendapatkan pengalaman apa yang ia dapatkan ketika ia seusia anaknya, lebih khususnya pengalaman pesantren. Untuk memenuhi biaya rumah tangga, K.H. Mas Abdurahman bertani seperti menanam pohon karet, kelapa, tanaman darat, menanam padi di sawah serta berjualan kitab-kitab hasil karangannya sendiri atau karangan orang lain yang dipergunakan untuk madrasah dan lain sebagainya.

K.H. Mas Abdurahman sudah tidak asing lagi di mata masyarakat Menes Banten, kepercayaan ini datang ketika ia mempunyai kekuatan luar biasa serta ketinggian ilmu yang telah

\footnotetext{
${ }^{8}$ Ibid. Hlm. 21
}

dipelajarinya baik itu di Nusantara maupun di Mekkah. Di Mekkah ia pernah belajar pada Kiai Nawawi AlBantani yang merupakan ulama terkenal yang mempunyai banyak murid, baik itu yang berasal dari Indonesia atau dari negara Islam lainnya yang mempunyai majelis di Masjidil Haram Mekkah bahkan K.H. Mas Abdurahman pernah dijadikan badal mengajar oleh Kiai Nawawi Al Bantani sehingga membuat ia dikenal luas oleh para pelajar terutama yang berasal dari Banten.

K.H. Mas Abdurahman mempunyai ayah yang merupakan salah seorang kiai yang dihargai di daerahnya namanya yakni Kiai Mas Jamal. Walaupun tinggal di sebuah dusun terpencil yang sukar dijangkau namun ia memiliki perhatian dan motivasi yang tinggi terhadap masa depan putranya. Ia berfalsafah "bahwa ia tidak ingin meninggal dunia sebelum putranya berhasil atau memiliki bekal ilmu pengetahuan yang memadai". 9

Atas dasar falasafah tersebut K.H. Mas Abdurahman mendapat pendidikan agama secara baik sejak masa kanak-

9 Falsafah itu artinya sebagaimana halnya pohon pisang walaupun ditebang beberapa kali tetap akan terus mengeluarkan tunasnya, setelah menghasilkan buahnya untuk beberapa kali baru ia rela untuk mati.lihat M. Nahid Abdurrahman, Abdurrahman: Pendiri Mathla'ul Anwar tahun 1916. (Rangkasbitung: Penerbit Tawekal, t.th) hlm 26 
kanak dari lingkungannya sendiri yakni dari ayahnya, yang mempunyai cita-cita yang tinggi karena ingin Mas Abdurahman menjadi alim ulama dan meneruskan pembelajarannya sampai ke Mekkah. Setelah menginjak usia remaja ia dikirim untuk melanjutkan studinya ke berbagai pesantren di Jawa Barat di antaranya kepada Kiai Sohib pemilik Pondok Pesantren Kedung Pinang, yang tidak jauh dari rumahnya. Ia juga belajar mengaji kepada Kiai Ma'mun yang terkenal dengan Bacaan Al-Qur'annya (Qiraah).

Merasa tidak puas dalam menuntut ilmu, Abdurahman remaja kemudian merantau ke Jawa Tengah untuk belajar di Pondok Pesantren Sarang, Rembang di bawah asuhan Kiai Arif dan Kiai Zubair, terutama untuk memperdalam ilmu Al-Qur'an dan ilmu Nahwu dan Sharaf. Untuk melengkapi keilmuannya, K.H. Mas Abdurahman belajar ilmu Tasawuf dan Tarekat di bawah bimbingan Kiai Tubagus Bachri dari Purwakarta, Jawa Barat.

Pada tahun 1903, Mas Abdurahman mendapat berita duka yakni ayahnya, Kiai Haji Mas Jamal, yang sedang melaksanakan ibadah haji di Mekkah meninggal dunia. Hal ini memaksanya untuk kembali ke kampung halaman pada saat itu juga. Namun demikian, semangatnya untuk meningkatkan pengetahuan agama tidak pernah padam. Hal itu terbukti pada tahun 1905, Mas Abdurrahman pergi ke Mekkah walaupun hanya mempunyai bekal cukup untuk ongkos pergi saja, tetapi dengan tekad dan kemauan keras beliau berangkat dengan tujuan menunaikan ibadah haji. Kepergiannya ke Mekkah mempunya dua tujuan utama. Pertama, ia ingin mencari makam ayahandanya walaupun tidak jelas di mana kuburannya karena kuburan di sana tidak memilkik tanda yang tertulis dalam batu nisan seperti di Indonesia, namun ia merasa puas dapat berziarah ke makam almarhum ayahandanya secara dekat. Kedua, ia ingin melanjutkan studi agamanya ke beberapa guru agama di sana yang sudah sangat terkenal di Nusantara, di antaranya Syaikh Nawawi al-Bantani ulama besar asal Banten, Syaikh Ahmad Khatib dari Minangkabaudan Syaikh Mahfuzh dari Termas. Untuk tujuan keduanya ini, semua hambatan dan tantangan telah dihadapinya, seperti hambatan karena terbatasnya uang saku, serta tantangan kondisi alam karena kondisi alam di Mekkah tidak seperti di Indonesia. ${ }^{10}$

${ }^{10}$ Dalam memenuhi kebutuhannya sehari-hari sangat sukar dipikirkan sebab bekal pun tak ada. Kadangkadang untuk memenuhi kebutuhan sehari-hari Mas Abdurahman pergi ke luar kota mencari kayu bakar 
Namun karena tekad dan keinginan yang kuat untuk menuntut ilmu pengetahuan telah tertanam dalam hati sanubarinya, segala hambatan dan kesusahan hidupnya tersebut dapat diatasinya dengan baik.

Seluruh pelajaran diikutinya dengan penuh perhatian dan ketekunan walau sarana serta peralatan menulis tidak lengkap, kebanyakan cukup mendengarkan. Tetapi keberhasilan dan kemahirannya dalam menyerap ilmu pengetahuan khususnya di bidang agama sangat mendalam, di antaranya ilmu tauhid, fiqih, bahasa Arab, tafsir, dan hadits. Dengan keberhasilannya tersebut, K.H. Mas Abdurahman direncanakan akan diangkat menjadi badal (Asisten Dosen) pengajian di Mesjidil Haram, tetapi hal ini tidak berlanjut, karena adanya permohonan dari para Ulama/Kiai Menes, Banten agar ia segera kembali ke tanah air.

K.H. Mas Abdurrahman adalah tokoh yang memiliki banyak karya

dan hasilnya ditukar dengan beras. Karena sangat sulitnya mendapatkan bahan makanan, beras tersebut dicampurkannya dengan pasir, satu sendok beras berbanding satu liter pasir ditambah air yang banyak, agar dikala makan dipilihlah butiran nasi satu persatu, perut menjadi kenyang akibat terlalu lama dan timbulnya rasa kesal memilih butiran nasi tersebut. Hal ini dilakukan hampir setiap hari selama sepuluh tahun, kecuali jika musim haji tiba karena banyak mendapat penghasilan dari hasil mengantar jemaa'ah haji yang berziarah. Lihat M. Nahid Abdurrahman, Abdurrahman: Pendiri Mathla'ul Anwar tahun 1916. Hlm 29 melalui sejumlah tulisan yang disusun. Sepanjang hidupnya, ia telah menulis beberapa buku tentang berbagai masalah keagamaan, di antaranya yaitu $A l$ Jawa'iz fi Ahkam al-Jana'iz tentang tata cara pemakaman jenazah menurut Islam, Ilm al-Tajwid tentang aturan baca AlQuran, Al-Takhfif tentang tata bahasa Arab, Miftah Bab al-Salam tentang hukum Islam, dan Fi Arkan al-Iman wa al-Islam tentang teologi. Semua buku ini ditulis dalam tulisan Melayu Arab (Jawi), dengan bahasa Sunda sebagai mediumnya. Semua buku ini dipersiapkan sebagai rujukan utama untuk studi-studi agama di Madrasah Mathla'ul Anwar. Dari sekian banyak karya K.H. Mas Abdurahman, buku AlJawa'iz fi Ahkam al-Jana'iz merupakan karya yang fenomenal karena buku tersebut sampai hari ini masih banyak dibaca, dan menjadi buku rujukan dalam pembelajaran di Mathla'ul Anwar. Buku ini tidak saja diperuntukan untuk para siswa namun dipakai juga untuk masyarakat umum.

Setelah beberapa lama menderita sakit dan masih ditakdirkan Allah untuk dapat mengambil air wudhu dan sholat walaupun dengan berbaring, akhirnya pada hari Rabu tanggal 27 Sya'ban 1363 H bertepatan dengan 16 Agustus 1944 dengan disaksikan oleh sebagian istri 
dan anak-anaknya, K.H. Mas Abdurahman pulang ke Rahmatullah untuk selama-lamanya. Beribu-ribu umat Islam hadir serta pejabat Pemerintah Jajahan Jepang dari Kabupaten Pandeglang dan Banten hadir untuk memberikan penghormatan terakhir kepada K.H. Mas Abdurahman yang dilakukan di daerah Cikaliung Sodong. ${ }^{11}$

\section{Gerakan Pembaharuan K.H. Mas}

\section{Abdurahman}

Pembaharuan yang dilakukan K.H. Mas Abdurahman ternyata berdampak luas pada para alumni madrasah yang ia dirikan. Para siswa yang pernah belajar pada sang guru memberikan dampak yang sangat positif terhadap kampung halaman mereka, di samping itu banyak santri yang mendirikan madrasah cabang di daerahnya masing-masing yang menginduk pada madrasah pusat.

Beberapa implikasi pembaharuan

K.H. Mas Abdurahman yaitu :

\section{Implikasi Dalam Bidang}

Pendidikan

Modernisasi dalam bidang

pendidikan setidaknya meliputi 4 unsur diantaranya: Sistem pendidikan, kurikulum, metode pembelajaran, dan

${ }^{11}$ M. Nahid Abdurrahman, Abdurrahman: Pendiri Mathla'ul Anwar tahun 1916 (Rangkasbitung: Penerbit Tawekal, t.th.), hlm 25 evauasi pembelajaran. Di bidang pendidikan K.H. Mas Abdurahman melakukan beberapa pembaharuan diantaranya:

a. Pengelolaan Sistem Madrasah

Banten mengenal dua macam sistem pendidikan Islam sebelum berdirinya madrasah Mathla'ul Anwar pada tahun 1916, yakni langgar dan pesantren. ${ }^{12}$

Seperti telah disebutkan sebelumnya, salah satu dorongan utama dibalik pendirian madrasah Mathla'ul Anwar, sesungguhnya modernisasi yang dilakukan adalah menyempurnakan dan bukan menggantikan. Langkah pertama untuk mewujudkan tujuan tersebut adalah dengan mendirikan sebuah madrasah berdasarkan sistem kelas. Sejak awal, para pendiri menyadari bahwa sistem pesantren dan langgar sudah ketinggalan zaman dan gagal menarik minat kaum muda Muslim. Oleh

12 Pesantren adalah sebuah lembaga pendidikan Islam tradisonal tertua di Indonesia, serta lembaga pendidikan non formal yang tumbuh dan berkembang pesat, sekaligus memberikan andil yang sangat besar terhadap pendidikan Indonesia, dari sebelum kemerdekaan, sampai sekarang masih dapat dilihat dimana-mana, khususnya di pedesaan, karena memang cikal bakal tumbuhnya pondok pesantren berada di tempat-tempat yang tergolong primitif, walaupun sekarang ini sudah masuk ke ranah perkotaan. Departemen Agama RI, Pola pengembangan Pondok Pesantren, ( Jakarta: Direktorat Jendral Kelembagaan Agama Islam, 2003, hlm. 3 
karenanya, mereka bermaksud menerapkan sistem pendidikan baru yang menggunakan sistem kelas dengan standar kurikulum baku dan jelas. Gagasan modernisasi pendidikan Islam telah tersebar luas di Nusantara ketika itu. Sejak tahun 1909 sejumlah sekolah Islam telah mengadopsi sistem kelas seperti Madrasah Adabiyah dan Sumatra Thawalib di Sumatra Barat. $^{13}$ Selain itu, Kiai Abdul Halim dari Majalengka, yang terkesan dengan modernisasi sistem sekolah di Makkah dan Jeddah, mendirikan organisasi modern yang diberi nama Hayatul Qulub.

\section{Modernisasi} sistem pendidikan Islam di Mekkah konon juga memberi kesan yang mendalam pada diri Mas Abdurrahman sehingga kemudian ia merintis gerakan modernisasi madrasah di Mathla'ul Anwar pada tahun-tahun sesudahnya.

Pada awalnya, pendirian sebuah madrasah dengan sistem kelas masih terhalang oleh tidak adanya tanah untuk membangun madrasah tersebut. Di samping itu,

${ }^{13}$ Deliar Noer, Gerakan Modern Islam di Indonesia 1900-1942, Jakarta : LP3ES, 1973. hlm.69-70. kurangnya dana semakin mempersulit masalah. Namun demikian, masalah tanah segera terpecahkan ketika Kiai Mustaghfiri, salah seorang anggota pendiri Mathla'ul Anwar memberikan rumahnya sebagai ruang kelas sementara. Dengan memanfaatkan fasilitas seadanya tersebut, Mas Abdurrahman, selaku mudir pendidikan, membuka madrasah ini secara resmi pada tanggal 9 Agustus 1916 M yang bertepatan dengan 10 Syawwal $1334 \quad$ H. $^{14}$ Untuk memulai itu semua, ia menyusun kurikulumnya, melakukan rekruitmen guru sekaligus bertindak sebagai pengendali mutu seluruh kegiatan proses belajar mengajar.

Setelah berjalan selama beberapa bulan, madrasah mendapat sambutan positif dari masyarakat baik dalam bentuk kepercayaan maupun bantuan lainnya. Para penduduk sekitar mengirimkan anak-anak mereka untuk belajar. Banyaknya murid yang belajar di Mathla'ul Anwar

\footnotetext{
Aceng Abdul Qodir, Biograpi KH Mas Abdurahman Mengenai Didaktik Methodiknya Dalam Pendidikan Islam., Skripsi, Sekolah Tinggi Agama Islam Mathlaul Anwar (STAIMA) Cikaliung . 1999 .hlm. 55.
} 
telah berhasil meyakinkan orang kaya setempat yang bernama Ki Demang Entol Jasudin untuk mewakafkan tanahnya untuk pendirian madrasah. Dengan bantuan dan dukungan dana dari masyarakat sekitar, Mathla'ul Anwar akhirnya mampu mendirikan bangunan madrasah yang pertama yang menjadi pusat kegiatan pendidikan Islamnya hingga sekarang. Madrasah ini menggunakan perlengkapan modern untuk ukuran saat itu seperti papan tulis, bangku, dan meja, meskipun belum mewajibkan seragam tertentu bagi para siswanya yang seluruhnya masih mengenakan sarung. Menurut beberapa alumni pertama, para siswa mulanya merasa tidak nyaman karena mereka tidak pernah menggunakan alat-alat seperti itu untuk belajar di pesantren.

Pada tahun 1929, Mathla'ul Anwar mendirikan madrasah khusus putri. Namun bangunan madrasah tersebut terpaksa dipisahkan dari madrasah utama yang dikhususkan untuk laki-laki. Pendirian madrasah putri menunjukan bahwa Mathla'ul
Anwar mempunyai pandangan yang lebih maju dan tegas tentang kedudukan wanita dibandingkan dengan pemahaman yang berkembang di masyarakat saat itu yang masih mengganggap tugas wanita tidak lebih dari bertugas di dapur dan melayani suami serta mengurus anak dan kehidupan sehari-hari saja. Dengan adanya Madrasah Putri Mathla'ul Anwar posisi wanita dalam penguasaan ilmu memiliki hak yang sama dengan laki-laki.

Pada tahun 1938 Mathla'ul Anwar menerbitkan aturan tentang sistem persekolahan baru dengan urutan sebagai berikut Madrasah Awwaliyyah atau pra-sekolah dasar (dua tahun), Madrasah Ibtidaiyah (enam tahun), Madrasah Tsanawiyah (tiga tahun), dan Madrasah Muallimin Wustha (dua tahun), dan Madrasah Muallimin 'Ulya yang setara dengan tingkat universitas (tiga tahun). Para siswa yang ingin menamatkan pendidikan mereka di madrasahmadrasah ini harus menempuhnya selama enam belas tahun.

Banyaknya pemimpin yang menolak gagasan penyatuan menjadi alasan pemisahan tersebut. 
Untuk mengelola madrasah ini, Mathla'ul Anwar mengangkat Hajjah Siti Zainab, putri Kiai Entol Yasin sekaligus menantu Kiai Tubagus Sholeh sebagai direktur. Mathla'ul Anwar juga mengangkat Nyi Kulsum dan Nyi Afiyah sebagai guru sekaligus membantu tugas direktur. Di bawah kepemimpinan mereka, madrasah putri berkembang pesat dimana ratusan siswi banyak yang ikut belajar di madrasah tersebut.

Kembali ke madrasah untuk murid laki-laki, di tahun-tahun awal berjalannya madrasah ini, K.H. Mas Abdurahman mengajar di madrasah. Pada saat yang sama, juga bertugas merekrut guru-guru dari kalangan kiai muda di Menes seiring dengan bertambahnya kelas. Di antara yang direkrut adalah Kiai Hamdani, Kiai Abdul Latif dan lain-lain. Pada akhir 1920an, ada sembilan guru yang mengawasi sembilan kelas. Setelah dirasa cukup memadai, Mas Abdurrahman mengundurkan diri dari kegiatan mengajar dan memutuskan untuk memusatkan perhatian pada tugas-tugasnya sebagai mudir urusan pendidikan.
Pada tahun pertama pendirian madrasah siswa-siswanya ia datangkan dari sekitar Menes. Kebanyakan dari mereka adalah santri-santri seperti santri dari pesantrennya Kiai Haji Muhamad Soleh dari Kananga, santri dari pesantren Kiai Haji Arsyad dari Tegal dan tempat-tempat lainnya. Selain itu ternyata sambutan masyarakat untuk memasukan anaknya ke madrasah yang didirikan oleh K.H. Mas Abdurahman sangat menggembirakan sehingga untuk tahun kedua tidak tertampung lagi tempat belajarnya.

b. Penerapan Sistem Klassikal

Metode pembelajaran adalah suatu pengetahuan tentang cara-cara mengajar yang dipergunakan oleh guru atau instruktur. Metode yang digunakan di pesantren adalah metode sorogan atau bandongan, K.H. Mas Abdurahman memandang metode tersebut harus diperbaharui, maka ia memberikan masukan untuk metode yang digunakan di madrasah Mathla'ul Anwar yaitu metode klasikal.

Penyelenggaraan program pendidikan yang dilaksanakan di 
Mathla'ul Anwar ialah dengan menggabungkan sistem madrasah dengan sistem pesantren. Penggabungan dua sistem ini dianggap penting karena tujuan utama pendidikan Mathla'ul Anwar ketika itu ialah untuk menghasilkan calon-calon $d a^{\prime} i$ profesional yang luas wawasan keilmuannya dan mulia akhlaknya. Penggabungan sistem ini dianggap cukup tepat mengingat bahwa tujuan pendidikan agama tidak hanya terletak pada segi pengetahuan semata tetapi juga meliputi aspek penghayatan, pengamalan dan pembiasaan ibadah serta kesopanan dan kehalusan budi pekerti.

Pada awalnya para siswa atau santri mengalami kesulitan mengikuti sistem ini, karena mereka sebelumnya terbiasa dengan kultur dan sistem pesantren yang lebih longgar dalam disisplin dan jadwal waktu belajar. Para santri biasanya mengikuti proses belajar pola sorogan atau bandongan dengan gaya santai dan bebas, adakalanya santri mengikuti pengajaran dengan duduk bersila, dengan meluruskan kaki ke depan, duduk dengan bertumpu pada satu kaki dan kaki yang lain dilipat ke atas. Namun, biasanya kiai memakluminya karena cara ini biasanya dilakukan oleh santri yang mubtadiin.

Di pesantren sistem yang digunakan adalah sistem tutorial dengan cara bandongan atau sorogan. Cara bandongan adalah sekelompok santri antara lima sampai lima ratus orang mendengarkan seorang guru yang membaca, menerjemahkan, dan menerangkan dan seringkali mengulas buku-buku Islam berbahasa Arab. Sedangkan cara sorogan ialah seorang murid menghadap guru untuk membacakan dan menerjemahkan sebuah buku Islam dalam bahasa arab, kemudian sang guru mendengarkan sekaligus melakukan koreksi bahkan terkadang diselingi dengan ulasan yang singkat. ${ }^{15}$

Namun Madrasah Mathla'ul Anwar menerapkan sistem klasikal. Dari tahun 1916 hingga 1920, Mathla'ul Anwar menjalankan tiga kelas yang terdiri dari kelas A, B, dan I yang

15 Zamakhsyari Dhofier,Tradisi Pesantren, 1994. Jakarta:LP3ES. HIm 28 
masing-masing berlangsung selama setahun pelajaran. Pada tahun 1920, Mathla'ul Anwar memperluas jumlah kelasnya menjadi tujuh kelas untuk setiap satu tahun angkatan yang terdiri dari kelas A, B, I, II, III, IV, V. Pada tahun 1927, Entol Junaedi, putra K.H. Muhamad Entol Yasin dan baru saja pulang dari belajar di Universitas Al-Azhar Kairo, mengusulkan perluasan lagi jumlah kelas. Gagasan ini diterima dan dijalankan pada tahun itu juga. Hasilnya, Mathla'ul Anwar mulai membuka sembilan kelas untuk setiap satu tahun pelajaran mulai dari A, B, I hingga VII. Pola sembilan kelas ini berlanjut hingga tahun 1950 ketika sistem ini dirubah untuk disesuaikan dengan sistem pendidikan nasional yang merupakan hasil reformasi yang diperkenalkan oleh pemerintah Indonesia merdeka.

c. Pembaharuan Kurikulum

Dalam bidang pendidikan, kurikulum merupakan unsur penting dalam setiap bentuk dan model pendidikan yang mana pun. ${ }^{16}$ Tanpa adanya kurikulum,

16 Dr. Oemar Hamalik, 1999, Kurikulum dan Pembelajaran, Jakarta : Bumi Aksara hlm 23 sulit rasanya perencana pendidikan dalam mencapai tujuan pendidikan yang diselenggarakannya. Pada kenyataannya, sebagian pihak memang ada yang memahami kurikulum itu hanya dalam arti kata yang sempit, yaitu kurikulum dipandang sebagai rencana pelajaran yang harus ditempuh atau diselesaikan siswa guna mencapai suatu tingkatan tertentu.

Di pesantren, kurikulum yang digunakan adalah disesuaikan dengan kemampuan kiai, jika kiai mahir di bidang aqidah maka kurikulum yang diajarkan adalah kitab atau mata pelajaran yang berkaitan dengan bidang aqidah. Namun K.H. Mas Abdurahman melakukan pembaharuan dengan memasukan mata pelajaran umum seperti berhitung, membaca, bahasa Inggris, dan ilmu alam.

Pada masa kepemimpinan K.H. Mas Abdurahman sebagai mudir urusan pendidikan, K.H. Mas Abdurrahman memiliki kekuasaan penuh untuk menyusun kurikulum bagi madrasah. Kurikulum yang dilaksanakan di madrasah Mathla'ul Anwar umumnya adalah pengajaran kitabkitab agama (Kitab Kuning) dan 
kitab-kitab lain yang bersifat penunjang. Ia menetapkan bacaan yang akan dipelajari dan diawasi secara langsung. Selain itu, ia menyusun beberapa buku untuk digunakan di madrasah, seperti 'Ilm al-Tajwid, Nahwu alJamaliyyah, 'Ilm al-Bayan dan kitab-kitab kecil lainnya yang telah disebutkan sebelumnya. Kurikulum yang ia susun juga memasukkan unsur keterampilan seperti pelatihan dakwah dalam bentuk muqabalah (layanan masyarakat) dengan pengiriman murid dari kelas enam hingga delapan untuk berdakwah secara langsung kepada masyarakat di desa-desa sekitar. Pelatihan ini dilaksanakan setiap Kamis.

Proses belajar mengajar madrasah Mathla'ul Anwar dimulai pada pukul delapan pagi sampai pukul dua belas siang dengan waktu istirahat sekali selama kurang lebih setengah jam. Waktu libur yang dijadwalkan ialah hari Kamis dan Jum'at. Pada hari Kamis diadakan kursus atau pengajian untuk menambah ilmu pengetahuan bagi dewan guru yang diberikan oleh K.H. Mas
Abdurahman yang bertempat di mesjid Soreang.

Pada akhir tahun 1930an, Mathla'ul Anwar menambah beberapa mata pelajaran umum dalam kurikulumnya seperti bahasa Indonesia, sejarah dunia, geografi dan beberapa ilmu alam. Masuknya mata pelajaran umum dalam kurikulum lembaga pendidikan Islam bukanlah hal baru, karena sejumlah sekolah modern Islam telah mengadopsinya sejak dekade kedua abad kedua puluh seperti Muhammadiyah, Al-Jami'ah alIslamiyah dan Sekolah Sumatra Thawalib di Sumatra Barat. Sejak itu, kebanyakan madrasah di Nusantara memasukkan mata pelajaran umum dalam kurikulum mereka, meskipun berbeda-beda presentasenya dibandingkan dengan pelajaran agama. ${ }^{17}$

d. Evaluasi Pembelajaran

Aspek penting lain dalam teknologi pengajaran adalah evaluasi atau penilaian. Evaluasi atau penilaian dalam pengajaran tidak semata-mata dilakukan terhadap hasil belajar, tetapi juga

\footnotetext{
${ }^{17}$ Mahmud Yunus, Sejarah Pendidikan Islam. PT Hidakarya Agung, Jakarta, 1996.Hlm. 102-104.
} 
harus dilakukan terhadap proses pengajaran itu sendiri ${ }^{18}$. Dengan evaluasi tersebut dapat dilakukan revisi program pengajaran dan strategi pelakasanaan pengajaran. Dengan kata lain, ia dapat berfungsi sebagai umpan balik dan remedial pengajaran.

Di pesantren, tidak ada evaluasi dalam mengukur sejauh mana santri dalam menguasai materi pembelajaran, serta santri kebanyakan lama sekali dalam mengikuti pembelajaran, oleh sebab itu K.H. Mas Abdurahman mengadakan evaluasi terhadap hasil pembelajaran melalui ujian yang dilakukan pada akhir setiap tahun akademik (haul), siswa madrasah Mathla'ul Anwar akan mengikuti ujian akhir. Mereka yang lulus ujian akan naik ke kelas berikutnya. Sementara bagi yang gagal, mereka harus mengulang kelas yang sama selama setahun lagi. Madrasah juga memiliki aturan program akselerasi dengan mengizinkan siswa unggul untuk melewati satu atau dua kelas. Misalnya, Sarnaka konon merampungkan seluruh sembilan

18 Sukardi M,Evaluasi Pendidikan Prinsip dan Operasionalnya. Jakarta: Bumi Aksara, 2008, Hlm 25 tahun hanya dalam waktu empat tahun saja. K.H. Mas Abdurrahman beserta beberapa guru senior yang ditunjuk secara langsung menyelenggarakan ujian tersebut. K.H. Mas Abdurrahman bahkan bertindak sebagai penguji. Menurut beberapa mantan muridnya, ujian tersebut berlangsung sangat ketat. Sementara dari sisi waktu pelaksanaanya, ujian akhir tersebut biasanya diadakan pada bulan Safar dan Rabi'ul Awwal. ${ }^{19}$

Setelah ujian selesai, ada acara tahunan (Ihtifalan) untuk menandai berakhirnya tahun ajaran tersebut. Acara ini biasanya diselenggarakan pada tanggal 20 Rabi'ul-Tsani. Dalam acara ini, mereka yang menamatkan pelajaran merayakan kelulusan dan pada saat itu pula Mathla'ul Anwar memberikan ijazah bagi mereka yang telah menamatkan sembilan tahun masa belajar. Ijazah ini dipandang sebagai lisensi bagi para alumni untuk mengajarkan pengetahuan Islam di madrasah lain atau bahkan mendirikan madrasah sendiri.

\footnotetext{
19 Aceng Abdul Qodir, Biograpi KH Mas Abdurahman Mengenai Dikttatik Methodiknya Dalam Pendidikan Islam, hlm. 65.
} 


\section{Implikasi Dalam Bidang Dakwah ( Majelis Taklim)}

K.H Mas Abdurahman memiliki pemikiran dan pemahaman yang dalam mengenai ilmu-ilmu ke-Islaman. Ia menguasai ilmu tauhid, fiqih, bahasa Arab, tafsir, dan hadits dan lain-lain. Oleh sebab itu, tidaklah berlebihan kalau K.H. Mas Abdurahman mampu merespon dan menjawab persoalanpersoalan keagamaan yang berkembang saat itu. Melalui kitab-kitab yang ditulisnya dalam berbagai disiplin ilmu, ia mampu menjawab harapan masyarakat dan menjawab permasalahan tersebut.

Semenjak adanya K.H. Mas Abdurahman, gerakan dakwah ulama di Menes semakin semarak dan meningkat. Dengan gencarnya tabligh dakwah dalam rangka amar ma'ruf nahi mungkar secara berkesinambungan terus dilakukan, masuk kampung keluar kampung, menuruni jurang menaiki gunung dikerjakan tanpa mengenalkan lelah, baik siang ataupun malam. K.H. Mas Abdurahman selalu siap hadir dalam pertemuan-pertemuan, hajat perkawinan, khitanan, tahlil dan aqiqah yang selalu diisinya dengan ceramah. Di samping itu kegiatan memberikan pengajian-pengajian rutin bagi kaum bapak dan kaum ibu di Menes, Majau, Sodong, dan Langensari terus dilakukan dan bertambah semarak.

Dalam menyebarkan ajaran-ajaran Islam K.H. Mas Abdurahman menggunakan majelis ta'lim sebagai sarana mensyiarkan Islam. Salah satu materi wajib yang dipelajari adalah tentang pemikiran-pemikiran K.H. Mas Abdurahman yang dituangkannya dalam berbagai karya, seperti Al-Jawa'iz fi Ahkam al-Jana'iz, kitab berbahasa Sunda. Kitab ini telah dicetak ulang berpuluh kali dan sampai sekarang masih dipakai oleh majlis-majlis ta'lim di wilayah Banten.

K.H. Mas Abdurahman dalam menjalankan misi dakwahnya agar sampai pada masyarakat adalah dengan menulis buku Al-Jawa'iz fi Ahkam alJana'iz. Tujuannya adalah memberikan pemahaman kepada masyarakat tentang tuntunan ritual setelah kematian. Kitab ini ditulis dalam bahasa sunda, tujuannya agar nilai-nilai keislaman bisa ditransformasikan secara langsung dan mudah dipahami dan diterima oleh masyarakatnya.

K.H. Mas Abdurahman menulis Al-Jawaiz fi Ahkam al-Janaiz dalam bahasa Sunda dengan menggunakan tulisan Jawi. Dalam menyusun teks, ia 
juga menggunakan harakah. ${ }^{20}$

Penggunaan harakah itu dianggap biasa karena orang-orang Banten akrab dengan tulisan Arab dan Jawi. ${ }^{21}$

Menurutnya, orang-orang Banten sangat dekat dengan sinkretisme karena praktik-praktik menggabungkan aktivitas Islam yang benar dengan tradisi lokal dapat dilihat dalam hal-hal yang berkaitan dengan prosedur kepengurusan terhadap jenazah yang menjadi topik utama dari buku ini. K.H. Mas Abdurahman setidaknya memiliki dua tujuan ketika ia menulis buku ini. Pertama, ia bertujuan untuk menjelaskan ajaran sebenarnya dari Ahl al-Sunnah wa al-Jama`ah tentang hal-hal yang berkaitan dengan kematian dan ritual. Dalam menguraikan subjek yang penting ini, karyanya itu disebut sebagai "buku terkenal dan terpercaya dari para ulama Ahl al-Sunnah wa al-Jama 'ah". Tujuan kedua dalam penerbitan Al-Jawaiz fi Ahkam al-Janaiz adalah bahwa kematian adalah fase terakhir dari kehidupan seseorang. Kesalahan dalam menangani

20 Harakah adalah poin vokal yang menandai gerakan organ artikulasi diperoleh melalui suara terhubung tertentu ketika seseorang mengatakan dan membaca dalam bahasa Arab. Didin Nurul Rosidin, "Membangun Identitas Mathla'ul Anwar: Sebuah Studi K.H. Mas Abdurrahman Al-Jawāiz fi Ahkam al-Janāiz" Fotokopian makalah ada di tangan penulis.

${ }_{21}$ Didin Nurul Rosidin, "Membangun Identitas Mathla'ul Anwar: Sebuah Studi K.H. Mas Abdurrahman Al-Jawāiz fi Ahkam al-Janāiz”, Fotokopian makalah ada di tangan penulis. mayat bisa merubah nasib seseorang di akhirat. K.H. Mas Abdurahman bereaksi marah ketika di Banten ritual penguburannya yang bercampur dengan berbagai praktik takhayul. Dengan kata lain, umat Islam diwajibkan untuk menjaga ritual penguburan murni seperti yang diajarkan oleh Nabi. Dalam buku ini, K.H. Mas Abdurahman tidak hanya menguraikan semua hal yang berkaitan dengan prosedur ritual terkait dengan almarhum saja, tetapi juga menyentuh beberapa hal yang berkaitan erat dengan kematian.

Tradisi lainnya yang berhadapan dengan perilaku yang benar dari tetangga almarhum. K.H. Mas Abdurahman menjelaskan bahwa para tetangga itu yang harus menyediakan makanan dan keperluan lainnya, bukan sebaliknya. Menurutnya, tradisi ini adalah takhayul karena Nabi jelas mengajarkan bahwa umat Islam lainnya harus memberikan bantuan terhadap keluarga yang tertimpa musibah itu.

Di bagian terakhir K.H. Mas Abdurrahman memberikan beberapa saran bagi umat Islam untuk mencapai apa yang disebut akhir hidup yang baik (husn al-khotimah) dan untuk menghindari perilaku yang akan membawa umat Islam kepada akhir yang buruk dari kehidupannya (shu`u al 
khotimah). Dalam menjabarkan uraiannya tersebut, K.H. Mas Abdurrahman memberikan definisi yang jelas tentang agama berdasarkan cara pandang dirinya dan sesama anggota dari Mathla'ul Anwar sesuai dengan konstitusi sebagai pengikut sejati Ahl alSunnah wa al-Jamā’ah.

Setiap pengajian, kitab yang dijadikan bahasan adalah Kitab AlJawa'iz fi Ahkam al-Jana'iz, kitab ini juga dapat dikatakan sebagai langkah baru di tengah tradisi tulis-baca di dunia pesantren yang belum cekatan dalam menghasilkan karya yang utuh. Banyak masyarakat di wilayah Banten mempergunakan kitab ini dalam proses kematian dan ritual. Begitu juga, pengajian kampung di lingkungan masyarakat yang dibimbing oleh K.H. Mas Abdurahman, baik yang dilakukan secara rutin (berkala) maupun pada waktu tertentu (insidentil).

Selain itu, usaha-usaha terus dilakukan untuk memberantas praktekpraktek keagamaan yang menyimpang. Misalnya, melalui Kitab Al-Jawa'iz fi Ahkam al-Jana'iz, K.H. Mas Abdurahman menentang berbagai praktek keagamaan yang tidak sesuai dengan ajaran-ajaran Islam seperti selamatan yang dihadiri masyarakat di rumah keluarga dari orang yang meninggal pada hari pemakaman dan pembacaan tahlil beberapa hari setelahnya untuk penebusan dosa yang meninggal. Alih-alih dia menyarankan agar para tetangga membantu keluarga tersebut dengan menyediakan makanan di hari duka cita.

Penolakan yang keras terhadap selamatan dan tahlil tidak berarti K.H. Mas Abdurahman sepenuhnya menolak ritual itu sendiri, karena ia melihat manfaat ritual ini, khususnya dalam kaitannya untuk meningkatkan kesadaran keagamaan di antara masyarakat awam. K.H. Mas Abdurahman menganggap tahlilan diperbolehkan oleh agama, namun ia mengkritik gagasan untuk melaksanakan ritual ini selama sejumlah beberapa hari.

Secara tradisi, selain sejumlah hari setelah pemakaman, keluarga yang berduka cita juga akan menyelenggarakan selamatan di hari-hari selanjutnya seperti menyediakan makanan selama tujuh malam bagi yang membaca Al-Qur'an (terutama Surat Yasin dan do'a-do'a). Selain itu pula tradisi berdo'a pada empat puluh, keseratus, dan keseribu hari dari wafatnya jenazah, K.H. Mas Abdurahman menolak gagasan ini.

\section{Implikasi Bagi Masyarakat Banten}


Pembaharuan yang dilakukan K.H. Mas Abdurahman mempunyai dampak yang luar biasa. Dengan didirikannya madrasah oleh K.H. Mas Abdurahman tidak dapat dipungkiri bahwa pendidikan yang diajarkan oleh K.H. Mas Abdurahman itu membawa manfaat juga bagi pribumi, khususnya bagi ummat Islam. Sebelumnya telah dijelaskan pada bab di atas bahwa K.H. Mas Abdurahman dengan madrasahnya tidak hanya memberantas kebodohan, tetapi juga mengubah masyarakat dari jurang kegelapan menuju sebuah masyarakat yang sehat dan produktif, serta menjadi individu yang siap menjadi pemimpin dalam segala bidang.

Selain itu, orang-orang pribumi bisa mengenal sistem pendidikan modern, misalnya sistem kelas, pemakaian papan tulis, meja dan bangku. Dari segi metode belajar-mengajar modern dan ilmu pengetahuan umum. Menciptakan orang-orang pribumi terpelajar yang cerdas, pintar, berwawasan luas, dan memiliki pola pikir yang rasional. Sisi-sisi positif madrasah itu telah melahirkan gagasan di kalangan ulama dan tokoh Islam di Banten.

Di bidang keagamaan, perayaan maulid Nabi Muhamad SAW dirayakan dengan melantunkan dzikir dan shalawat, serta pujian kepada Nabi Muhamad sebagai bukti kecintaan terhadap nabi. Selain itu, masyarakat membuat tumpeng sebagai wujud syukur atas kelahiran orang yang dicintai.

K.H. Mas Abdurahman pada awalnya hidup dengan rukun bersama masyarakat sekitar, namun dengan dengan hadirnya K.H. Mas Abdurahman dan pendirian madrasah mendapat tanggapan yang beragam dari masyarakat seperti adanya penolakan dari masyarakat karena tradisi yang sudah turun temurun dilakukan dilarang keras oleh K.H. Mas Abdurahman seperti tradisi upacara mipit, upacara walimah yang masih mempertahankan bid'ah, khufarat dan takhayul.

\section{Implikasi Bagi Pemerintah Kolonial}

Sebelum mendirikan madrasah Mathla'ul Anwar, K.H. Mas Abdurahman sudah menghadapi banyak tantangan yang tidak menyenangkan terutama dari pemerintah Belanda. Sebagaimana lazimnya pemerintah kolonial, maka setelah dilihatnya bahwa gerakan yang dipelopori K.H. Mas Abdurahman itu sangat berpengaruh bagi rakyat. Apalagi setelah meletusnya pemberontakan tahun 1926 banyak para kiai dan ulama yang terlibat, maka pemerintah kolonial mulai mengadakan 
pengawasan yang ketat termasuk juga mengawasi pengajian yang dipelopori oleh K.H. Mas Abdurahman.

Pengajian terus diikuti oleh matamata sehingga pergerakan menjadi terbatas. Namun meski demikian aktivitasnya tetap berjalan lancar. Selain itu pula cara lain digunakan seperti memberikan jabatan sebagai penghulu oleh pemerintah kolonial, namun K.H. Mas Abdurahman menolaknya dengan halus. Bahkan pernah suatu ketika utusan pemerintah kolonial Belanda menemui beliau untuk mempengaruhi dan memberikan padangan agar beliau dengan kawan-kawannya tidak meneruskan pergerakannya, tetapi ia dan kawan-kawannya tetap pada pendiriannya serta tidak gentar menghadapi pengaruh pihak-pihak kolonial.

\section{Penutup}

Dari uraian di atas dapat diambil kesimpulan:

1. KH Mas Abdurahman adalah salah seorang pendiri organisasi Mathla'ul Anwar yang artinya tempat terbitnya matahari, di Banten bersama sembilan tokoh Islam lainnya. KH Mas Abdurahman dilahirkan di daerah Janaka, Pandeglang.

2. Gerakan pembaharuan yang dilakukan KH Mas Abdurahman di Mathla'ul Anwar adalah sebagai seorang direktur (mudir) untuk urusan pendidikan dan urusan dakwah di Mathla'ul Anwar memberikan ruang yang begitu luas dalam melakukan pembaharuan dantaranya menciptakan lembaga pendidikan Islam atau madrasah yang modern dengan menerapkan sistem pendidikan baru yang menggunakan sistem kelas dengan standar kurikulum baku dan jelas.Selain itu pula dalam KH Mas Abdurahman menggunakan Majelis Taklim sebagai alat untuk menyebarluaskan ilmu-ilmu keislaman. dan kitab-kitab yang karya KH Mas Abdurhman mempunyai pengaruh yang sangat penting bagi kehidupan masyarakat Banten salah satu kitabnya yang terkenal yaitu Al-Jawaiz fi Ahkam al-Janaiz tentang tata cara pengurusan jenazah.

3. Implikasi dari gerakan pembaharuan KH Mas Abdurahmandi bidang pendidikan yaitu pengelolaan sistem madrasah, penerapan sistem klasikal, dan pembaharuan 
kurikulum. Di bidang dakwah yaitu melalui majelis taklim dalam menjalankan misi dakwahnya. Gerakan pembaharuan KH Mas Abdurahman memberi implikasi yang besar bagi masyarakat dan pihak pemerintah kolonial yaitu mengubah masyarakat dari jurang kegelapan menuju sebuah masyarakat yang sehat dan produktif serta masyarakat mulai mengenal sistem pendidikan modern. Pemerintah kolonial memandang $\mathrm{KH}$ Mas Abdurhman adalah orang yang disegani dan sangat berpengaruh bagi masyarakat.

\section{Daftar Pustaka}

Abdul Qodir, Aceng. (1999).” Biograpi KH Mas Abdurahman Mengenai Didaktik Methodiknya Dalam Pendidikan Islam”. Cikaliung : Sekolah Tinggi Agama Islam Mathlaul Anwar (STAIMA)

Anonim. (1994)." Menapak Jejak Mengenal Watak, Sekilas Biografi 20 Tokoh Nahdlatul Ulama". Jakarta: Yayasan Saifuddin Zuhri

Azra, Azyumardi. (1998). "Jaringan Ulama Timur Tengah dan Kepulauan Nusantara Abad XVII dan XVIII: Melacak Akar-Akar Pembaharuan Pemikiran Islam di
Indonesia". Bandung : Penerbit Mizan.

Departemen Agama RI. (2003). "Pola Pengembangan Pondok Pesantren". Jakarta: Direktorat Jendral Kelembagaan Agama Islam.

Dhofier, Zamakhsyari. (1982) "Tradisi Pesantren". Jakarta: LP3S.

Hamalik, Oemar (1999). "Kurikulum dan Pembelajaran”. Jakarta : Bumi Aksara.

Kartodirjo, Sartono. (1987). "Pengantar Sejarah Indonesia Baru: 1.5001900: Dari Emperium Sampai Imperium Jilid I'. Jakarta: Gramedia.

M, Sukardi. (2008). "Evaluasi Pendidikan Prinsip dan Operasionalnya". Jakarta: Bumi Aksara.

Nahid, M Abdurrahman. (tth) "Abdurrahman: Pendiri Mathla'ul Anwar tahun 1916". Rangkasbitung: Penerbit Tawekal.

Noer, Deliar. (1973). "Gerakan Modern Islam di Indonesia 1900-1942““ Jakarta : LP3ES.

Rosyidin, Didin Nurul. (2012). “Wajah Baru Islam Indonesia ( Kontestasi Gerakan Keislaman Awal Abad 20". Cirebon: Nurjati Press.

Rosyidin, Didin Nurul. "Membangun Identitas Mathla'ul Anwar: Sebuah Studi K.H. Mas Abdurrahman AlJawāiz fi Ahkam al-Janāiz" Fotokopian makalah ada di tangan penulis.

Yunus, Mahmud. (1996). "Sejarah Pendidikan Islam". Jakarta: PT Hidakarya Agung. 